\title{
Failure of Self-Inflating Manual Resuscitator Due to the Presence of Dried Pulmonary Secretions
}

\author{
Armando Carlos Franco de Godoy ${ }^{1}$
}

\begin{abstract}
Summary: Godoy ACF - Failure of Self-Inflating Manual Resuscitator Due to the Presence of Dried Pulmonary Secretions.
Background and objectives: Self-inflating manual resuscitators (SIMR) are devices used to ventilate patients with ventilatory needs. These devices consist of a set of valves that work sequentially, and changes in their function may be harmful to patients.
\end{abstract}

Case report: During the use of SIMR, it was observed that the valve remained fixed due to the presence of dried pulmonary secretion, which made it impossible to ventilate the patient, but not manipulate the compressible unit.

Conclusions: This situation reaffirms that the resuscitator is a device that should be used by trained professionals because, although changes in functioning are rare, they can be potentially fatal.

Keywords: Respiration, Artificial; Cardiopulmonary Resuscitation; Equipment Failure Analysis; Pulmonary Edema.

[Rev Bras Anestesiol 2011;61(3): 351-354] @Elsevier Editora Ltda.

\section{INTRODUCTION}

Self-inflating manual resuscitators (SIMR) are devices used to provide positive pressure ventilation to patients requiring ventilatory support. Among the clinical situations in which SIMR are used, we could mention cardiopulmonary resuscitation, and extra- and intra-hospital transport 1,2 .

Self-inflating manual resuscitators cannot be regarded as simple devices, but rather a complex mechanism that consists of a set of valves that work sequentially to allow exhalation and entry of air in the respiratory system of the patient ${ }^{3}$.

Self-inflating manual resuscitators may have three parts: $\mathrm{O}_{2}$ reservoir(1), compressible unit(2), and patient connector(3). The $\mathrm{O}_{2}$ reservoir consists of a bag that receives the $\mathrm{O} 2$ flow and it is connected to the posterior portion of the compressible unit; the compressible unit is the part manipulated by the operator to provide breathing assistance to patients; while the patient connector is where the resuscitation mask or the proximal portion of the endotracheal tube is connected (Figure 1).

To operate the SIMR, the operator compresses the compressible unit, producing supra-atmospheric pressure in its interior, therefore making the disk-like valve(4) to block the outlet of the patient connector, directing air to the respiratory system; at the same time, the posterior valve(5) closes the

Received from Hospital das Clínicas da Universidade Estadual de Campinas (Unicamp), Brazil.

1. PhD, Professor; Physiotherapist responsible for the Emergência Clínica e Cirurgia do Trauma wards of Unicamp

Submitted on August 26, 2010.

Approved on December 7, 2010.

Correspondence to:

Dr. Armando Carlos Franco de Godoy

Rua Hercules Florence, 100/23

Botafogo

13020170 - Campinas, SP, Brazil

E-mail: armandogodoy@ig.com.b outflow of air through the posterior portion of the compressible unit. When the operator decompresses the compressible unit, it generates a subatmospheric pressure inside, opening the posterior vale and aspirating ambient air or oxygen from the $\mathrm{O}_{2}$ reservoir. Synchronically, the disk-like valve retracts until it reaches the protection plate of the patient connector(6), allowing the exhalation of air injected into the respiratory system. Some SIMRs have a pressure valve in the patient connector(7), which opens when the system reaches a pressure above $40 \mathrm{cmH}_{2} \mathrm{O}$, ensuring a pressure limit in the system (Figure 1).

\section{CASE REPORT}

During the SIMR use to change ventilators in a 65 year-old male patient with cardiogenic pulmonary edema, dependent

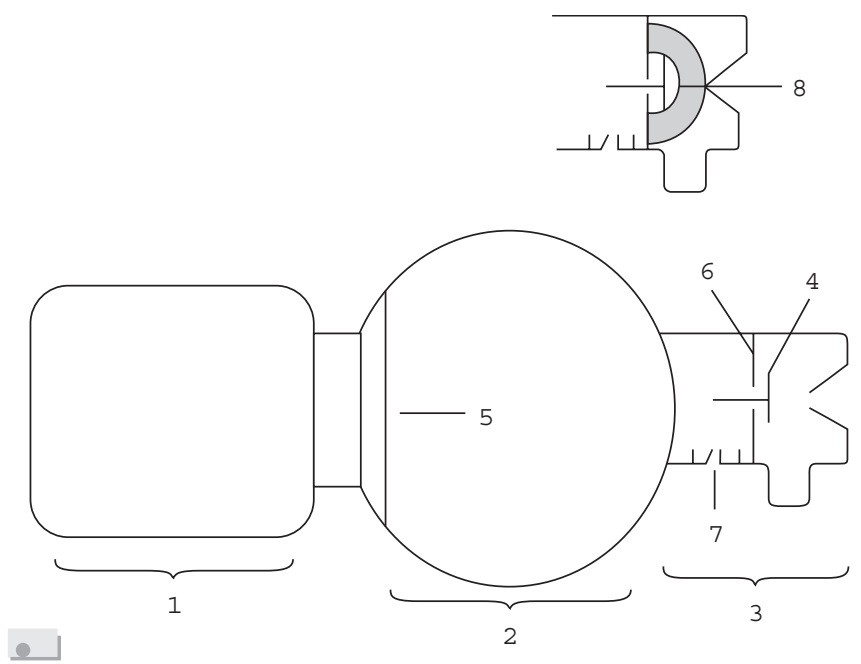

Figure 1 - Self-Inflating Manual Resuscitator Ccomponents. 
on invasive mechanical ventilation, it was observed that the patient had no chest expansion during manipulation of the compressible unit. Upon inspection of the equipment, it was observed that the disk-like valve was locked into the protection plate of the patient connector with a layer of dried pulmonary secretion (Figure 1)(8).

\section{DISCUSSION}

The situation presented here is consistent with the views of several authors who report that SIMR is a device to be used by a team of professionals properly trained and familiar with the components and the mechanism of its valves because, despite changes in SIMR valves being rare, they are real and can be fatal in specific clinical situations ${ }^{3,4}$.

It is possible to find in literature reports of patient's valve malfunctioning due to the fact that SIRMs are receiving high flow-oxigen ${ }^{5}$ and/or with erroneous assembly of its parts ${ }^{3}$. In these situations, authors reported difficulty or impossibility of manipulating the compressible unit ${ }^{3-11}$. This situation resulted in patient complications such as: pneumothorax ${ }^{6}$, gastric dila- tion and rupture with aspiration of gastric contents ${ }^{7}$, pneumoperitoneum ${ }^{8}$, esophageal rupture ${ }^{9}$, and pneumocephalus ${ }^{10}$.

In the present case, as the patient valve remained fixed by dried pulmonary secretions but the SIMR used had a pressure valve, the air then directed to the respiratory system was redirected to the environment and the compressible unit continued to be manipulated normally without ventilating the patient, though.

What led to the discovery of the SIMR malfunction was the patient's chest immobility. If the RMA had been used indefinitely under such circumstances, in situations like inter- or extra-hospital transport, cardiac arrest or endotracheal tube exchange, the patient could have develop hypoxemia worsening his clinical condition and even cause his death.

Although in our institution, SIMRs placed at the bedside are changed every 48 hours, it is not possible to determine how long it remained close to the patient without being used.

Self-inflating manual resuscitators should be used only by a team of professionals properly trained and familiar with its components and the function of its valves, as in some types the compressible unit can be manipulated by the operator without ventilating the patient. 


\section{REFERÊNCIAS / REFERENCES}

01. Miracle VA, Allnutt DR - Using a manual resuscitator correctly. Nursing, 1990;20:49-51.

02. Mazzolini Jr DG, Marshall NA - Evaluatio of 16 adult disposable manual resuscitators. Respir Care, 2004;49:1509-1514.

03. Smith $G$ - Problems with mis-assembly of adult manual resuscitators. Resuscitation, 2002;53:109-111.

04. Olver JJ, Pope R - Potential hazard, with silicone resuscitators. Anaesthesia, 1984;39:933-934.

05. Turki M, Young MP, Wagers SS et al. - Peak pressures during manual ventilation. Respir Care, 2005;50:340-344.

06. Cooper RM, Grgas S - Fatal barotrauma resulting from misuse of a resuscitation bag. Anesthesiology, 2000;93:892-893.

07. Weiler N, Heinrichs W, Dick W - Assesment of pulmonary mechanics and gastric inflation pressure during mask ventilation. Prehospital Disaster Med, 1995;10:101-105.

08. López Rodriguez A, López Sanchez L, Julia JA - Pneumoperitoneum associated with manual ventilation using a bag-valve device. Acad Emerg Med, 1995;2:944.

09. Sia RL - Role de l'anesthesiste-reanimateur dans les cas de rupture spontanee de l'oesophage. Can Anaesth Soc J, 1968;15:276-280.

10. Paradis IL, Caldwell EJ - Traumatic pneumocephalus: a hazard of resuscitators. J Trauma, 1979;19:61-63.

11. Godoy AC, Vieira RJ, Capitan EM - Alterations in peak inspiratory pressure and tidal volume delivered by manually operated self-inflating resuscitation bags as a function of the oxygen supply rate. J Bras Pneumol, 2008;34:817-821.

Resumen: Godoy ACF - Falla en el Funcionamiento del Resucitador Manual Autoinflable Debido a la Presencia de Secreciones Pulmonares Resecadas.

Justificativa y objetivos: Los resucitadores manuales autoinflables (RMA), son dispositivos utilizados para dar ventilaciones a pacientes con necesidad ventilatoria. Esos dispositivos están compuestos por un conjunto de válvulas que trabajan de forma secuencial y las alteraciones en su funcionamiento pueden ser dañinas para el paciente.

Relato del caso: Durante la utilización de RMA, observamos que la válvula permaneció fija debido a la presencia de secreción pulmonar resecada, lo que imposibilitó la ventilación del paciente, pero no la manipulación de la unidad comprensible.

Conclusiones: Esa situación muestra que el reanimador es un dispositivo que debe ser usado por profesionales entrenados, porque a pesar de que las alteraciones de funcionamiento sean algo raro, si ocurren pueden ser potencialmente fatales.

Descriptores: COMPLICACIONES: Edema pulmonar cardiogénico, Resucitación cardiopulmonar; EQUIPOS: resucitador manual autoinflable; REANIMACIÓN. 